\title{
Prenatal Diagnosis of Down Syndrome
}

\author{
Myungshin Kim, Jong Chul Shin and In Yang Park \\ The Catholic University of Korea, Seoul, \\ Korea
}

\section{Introduction}

Chromosomal aberration is a phenomenon occurring relatively commonly in the development process. Chromosomal aberration is known to have various causes, and its frequency has been reported to vary particularly according to maternal age. Though different among reports, the frequency was around $0.6-0.8 \%$ in analysis with all childbirths ${ }^{1}$ and around $2-3 \%$ in case childbirths were reclassified based on maternal age of $35 . .^{2}$ In addition, the frequency increased when the maternal age was relatively young, artificial insemination was used, etc. ${ }^{3}$ Spontaneous abortion related to such chromosomal aberrations occurs usually in the first trimester, and consequently, the prevalence of trisomy 21, 18 and 13 decreases with the advance of gestational age. ${ }^{4}$ Chromosomal aberrations that can be found in prenatal diagnosis are largely divided into aneuploidy, structural aberration, mosaicism, uniparental disomy, small defect, etc., and additionally, there can be marker chromosomes. Marker chromosomes are observed in around one out of 1000 cases of chromosomal analysis, and are known to be related to old maternal age. 5 It is reported that around $80 \%$ of marker chromosomes detected are new ones, and $13 \%$ of marker chromosomes are associated with physical abnormalities or cognitive disorders. ${ }^{6}$

The frequency and type of chromosomal aberration are known to be different depending on the time of evaluation, population group under the analysis of structural chromosomal aberration, and the banding level of the laboratory performing cytogenetic evaluation. ${ }^{7}$ Thus, it is increasingly important to conduct adequate prenatal genetic screening and analyze its results properly. Among chromosomal aberrations detected in pregnant women who received amniocentesis because of their age, $64 \%$ were trisomy ( $21 \%$ trisomy 21$), 11 \%$ translocation, $17 \%$ sex chromosomal aberration, and $8 \%$ other types of chromosomal aberration. ${ }^{2}$ Thus, considering the increasing number of old age pregnancies in Korea, careful attention should to paid in analyzing the results of prenatal genetic tests. Thus, this study purposed to discuss how to analyze the results of maternal serum marker tests and sonography used in prenatal genetic evaluation.

\section{Maternal serum screening}

\subsection{Alpha fetoprotein}

Brock and Sutcliffe 2 found in 1972 that the level of alpha fetoprotein in amniotic fluid increased when the fetus had a neural tube defect, and from the 1980s, the maternal serum alpha fetoprotein test began to be used for screening fetal anomalies in pregnant women. 
Alpha fetoprotein, which is glycoprotein, is produced in the yolk sac in the early stage, and later in the fetal gastrointestinal tract and liver. A small portion of alpha fetoprotein in fetal serum may be discharged to urine and amniotic fluid, and it may diffuse through the fetal membrane and the placenta and enter maternal serum. Whereas the alpha fetoprotein level in fetal serum and amniotic fluid increases until 13 week and then decreases thereafter, the level in maternal serum increases continuously until 32 week because the size of the fetus keeps growing. ${ }^{8}$ Between 16-20 week of gestational age, the level of alpha fetoprotein in maternal serum is only around $1 / 100,000$ of that in fetal serum.

\subsubsection{Analysis of serum alpha fetoprotein data}

As is known, the concentration of alpha fetoprotein in maternal serum or amniotic fluid is measured as a test for screening fetal neural tube defects. When the measurements of alpha fetoprotein are analyzed, we should be careful not to attach clinical importance to absolute values. It is because the test method of each laboratory or company may seem to have been stabilized by itself, but absolute values from the method are often different from those obtained by other laboratories or test methods. For this reason, the measurements of alpha fetoprotein are often reported as the multiples of the median (MoM). A median is the value in the middle when result values are put in order of size, so it can reduce errors and allow the comparative analysis of result values without being influenced by laboratory or test method.

On the other hand, the measurements of alpha fetoprotein in maternal serum can be affected not only by multiple pregnancy and gestational age but also by maternal weight, diabetes, race, etc. 9,10 , so these factors should be confirmed before the analysis of such measurements. Because the absolute level of serum alpha fetoprotein rises along with gestational age ${ }^{8}$, underestimated gestational age is the most common cause of increased alpha fetoprotein concentration. In such a case, we can avoid unnecessary additional tests by correcting gestational age and recalculating the median.

\subsubsection{Causes of increased alpha fetoprotein in maternal serum}

\section{Fetal anomalies}

The rise of the alpha fetoprotein level in maternal serum is often accompanied by fetal anomalies. This is not because of a special function of alpha fetoprotein but because fetal tissue leaks to amniotic fluid due to neural tube defect, abdominal wall defect, sacrococcygeal teratoma, cystic hygroma, skin defect, etc. and, as a result, an increasing amount of alpha fetoprotein flows into amniotic fluid and maternal serum ${ }^{11}$ or because alpha fetoprotein is not reabsorbed but discharged to urine due to fetal kidney anomaly. ${ }^{12}$

In fetal neural tube defect, alpha fetoprotein exudes through exposed nervous tissue, so the level of alpha fetoprotein in maternal serum is relatively higher in spina bifida aperta or anencephaly than in spina bifida occulta. In most laboratories, those whose median alpha fetoprotein level in maternal serum is over 2.0-2.5 are classified into a high-risk group of fetal neural tube defect. When median 2.5 was used, spina bifida aperta was detected at a detection rate of $80 \%$ and the false positive rate was $3-4 \% .13$

The anomaly found second most commonly to neural tube defect in alpha-fetoprotein screening is abdominal wall defect. Particularly in case of gastroschisis, organs removed out of the abdominal cavity contact amniotic fluid directly, and therefore, the alpha fetoprotein 
level tends to be higher than that in omphalocele. ${ }^{11}$ Maternal serum alpha fetoprotein screening detects around $85 \%$ of gastroschisis and around $50 \%$ of omphalocele. 11

\section{Placental abnormalities}

Because the concentration of alpha fetoprotein in fetal serum is 100,000 times higher than that in maternal serum ${ }^{8}$, even a small inflow of fetal blood increases the fetoprotein level in maternal serum rapidly. In case of chorioangioma in the placenta and hemangioma in the umbilical cord, fetal serum exudes into amniotic fluid and the maternal body due to mass bleeding ${ }^{14}$, and in case of placenta accreta, placental infarct, etc. as well, alpha fetoprotein increases in the same way. ${ }^{16}$

\subsection{Maternal serum test for aneuploidy screening}

\subsubsection{Second trimester multiple marker screening test}

In 1984, Merkatz et al. ${ }^{16}$ found that the risk of Down syndrome was high when the level of serum alpha fetoprotein was low during the second trimester, but this finding alone was not sufficient for using alpha fetoprotein as an accurate Down syndrome marker. ${ }^{16}$ Later, double marker test that added human chorionic gonadotropin (hCG) test, and triple test that added also estriol (E3) to the double test were introduced as Down syndrome screening tests in the second trimester. ${ }^{18}$ Recently, quad test that added inhibin A was developed ${ }^{18}$ for higher accuracy of screening. The mean median (MoM) of each marker in trisomy 21 and 18 is presented in Table 1. There were large-scale prospective studies that compared accuracy among a number of multiple markers in the U.K. (Serum, Urine and Ultrasound Screening Study; SURUSS) ${ }^{19}$ and the U.S. (First and Second Trimester Evaluation of Risk for Fetal Anueploidy; FASTER), ${ }^{20}$ and in both studies the detection rate of quad markers was reported to be $81 \%$. Table 2 summarized the Down syndrome detection rates of multiple markers from the two studies.

\begin{tabular}{ccccc}
\hline \hline Aneuploidy & AFP & hCG & uE3 & Inhibin A \\
\hline Trisomy 21 & $0.74^{*}(\downarrow)$ & $2.05^{*}(\uparrow)$ & $0.700^{*}(\downarrow)$ & $2.548^{*}(\uparrow)$ \\
Trisomy 18 & $0.65^{* *}(\downarrow)$ & $0.32^{* *}(\downarrow)$ & $0.42^{* *}(\downarrow)$ & - \\
\hline
\end{tabular}

AFP, a-fetoprotein; hCG, human chorionic gonadotropin; uE3, unconjugated estriol

* Modified from the results of the FASTER trial

** Modified from the results of Benn PA et al. Obstet Gyenecol 1999;93:707-11.

Table 1. The mean MoM (multiples of the median) values for the second trimester maternal serum quad markers.

\begin{tabular}{|c|c|c|c|}
\hline & & \multicolumn{2}{|c|}{$\begin{array}{l}\text { Detection rate at a } 5 \% \text { false- } \\
\text { positive rate }\end{array}$} \\
\hline & & SURUSS19 & FASTER 20 \\
\hline Double markers & $\mathrm{AFP}+\mathrm{hCG}$ & $66 \%$ & - \\
\hline Triple markers & $\mathrm{AFP}+\mathrm{hCG}+\mathrm{uE} 3$ & $74 \%$ & $70 \%$ \\
\hline Quad markers & $\mathrm{AFP}+\mathrm{hCG}+\mathrm{uE} 3+$ inhibin $\mathrm{A}$ & $81 \%$ & $81 \%$ \\
\hline
\end{tabular}

AFP, a-fetoprotein; hCG, human chorionic gonadotropin; $\mathrm{uE3}$, unconjugated estriol

Table 2. The detection rate of second trimester serum markers for Down syndrome. 


\subsubsection{First trimester screening test}

\section{Maternal serum triple marker test}

Among first trimester serum markers, pregnancy-associated plasma protein A (PAPP-A) and free $\beta$-hCG are known to have the highest discrimination for haploidy. In Down syndrome, the MoM of maternal serum PAPP-A is 0.38 , decreasing by $60 \%$, and that of free $\beta$-hCG is 1.83 , increasing by around two times. ${ }^{21}$ Accordingly, both of the two markers are used in first trimester screening, and with this test, the Down syndrome detection rate is 60$74 \%$ and the false positive rate is $5 \% .19,20$ The detection rate is lower than that of the quad test in the second trimester but similar to that of the triple test.

\section{Nuchal translucency measuring}

The thickness of nuchal translucency in the first trimester is related to fetal haploidy, in particular, to Down syndrome, apart from maternal serum markers. ${ }^{22}$ Accordingly, the accuracy of screening can be enhanced through the first trimester combined test that measures the thickness of nuchal translucency in addition to serologic tests that measure PAPPA-A and free $\beta$-hCG. ${ }^{22}$ In the results of a meta-analysis with 209,603 subjects, the combined screening test showed a detection rate of $86 \%(84-8895 \%, \mathrm{CI})$ with a false positive rate of $5.1 \%$ and Down syndrome was detected in 785 subjects. ${ }^{23}$ When only nuchal translucency was measured without serologic tests, the Down syndrome detection rate was $77 \%$ with a false positive rate of $6.0 \%$, so it was less accurate than the combined test. The positive predictive value of the combined screening test was 16.8 (16.3-17.4, 95\% CI), which means that one out of 17 pregnancies with a positive result of the combined screening test is found to have a Down syndrome fetus. ${ }^{23}$ On the other hand, because PAPP-A decreases but free $\beta$-hCG increases for 11-14 weeks of pregnancy, the detection rate varies significantly according to gestational age. ${ }^{23}$ In the results of FASTER, the Down syndrome detection rate was $73 \%$ and the false positive rate was $1 \%$ in 11 weeks of pregnancy, but $67 \%$ and $5 \%$, respectively, in 13 weeks, and based on this result the research reported that the accuracy of the combined test was highest at the gestational age of 11 weeks. ${ }^{20}$ However, it was reported that if second trimester screening would be performed additionally, it would be more efficient to have the combined test in 10 weeks of pregnancy. ${ }^{23}$

\subsubsection{First and second trimester integrated test}

Wald et al. ${ }^{24}$ proposed integrated test, which uses information on first and second trimester markers in sequence. They expected that if nuchal translucency and serum PAPP-A are measured in 10-13 weeks, and alpha fetoprotein, total hCG, estriol and inhibin A in 15-18 weeks, Down syndrome can be detected at a rate of $94 \%$ with a false positive rate of $5 \%$, or $85 \%$ with a false positive rate of $1 \% .25$ Accordingly, because Down syndrome can be screened with a false positive rate of $1 \%$, it reduces the need of additional diagnoses such as amniocentesis, and prevents fetal death resulting from invasive examination. In the results of SURUSS ${ }^{19}$ and FASTER, ${ }^{20}$ the integrated test was most accurate as a Down syndrome screening test (Table 3).

However, the integrated test has a number of shortcomings to be an alternative general screening test in prenatal examination. First, most of pregnant women who receive a screening test in the first trimester want the termination of pregnancy immediately if abnormalities are found in the fetus, and it is safer to terminate pregnancy in the first trimester. Second, it is hard to distinguish pregnant women who cannot be followed up after 
first trimester serologic tests. In SURUSS ${ }^{19}$ as well, $20 \%$ of pregnant women who had a first trimester test did not appear in the second trimester test. In such a case, there could be the legal risk of not telling the results of the first trimester test, so it was not an adequate alternative at present. Third, if the risk is unusually high in the results of the first trimester test the results are not provided until the second trimester, and this may raise an ethical issue. Thus, the integrated test can be the method of highest sensitivity and specificity if a pregnant woman receives prenatal examination from the beginning of pregnancy and takes both the first and second trimester screening tests, but is not adequate for those who want to get invasive chorionic villus sampling immediately based on the results of the first trimester screening test.

\begin{tabular}{|c|c|c|c|c|c|c|c|c|c|c|}
\hline & \multicolumn{5}{|c|}{ FASTER $\underline{20}$} & \multicolumn{5}{|c|}{ SURUSS 19} \\
\hline & \multicolumn{2}{|c|}{$\begin{array}{l}\text { FPR(\%) for } \\
\text { DR of }\end{array}$} & & \multicolumn{2}{|c|}{$\begin{array}{l}\text { DR(\%) for } \\
\text { FPR of }\end{array}$} & \multicolumn{2}{|c|}{$\begin{array}{l}\text { FPR(\%) for } \\
\text { DR of }\end{array}$} & & \multicolumn{2}{|c|}{$\begin{array}{l}\text { DR(\%) for } \\
\text { FPR of : }\end{array}$} \\
\hline & $75 \%$ & $85 \%$ & $95 \%$ & $1 \%$ & $5 \%$ & $75 \%$ & $85 \%$ & $95 \%$ & $1 \%$ & $5 \%$ \\
\hline \multicolumn{11}{|l|}{$1^{\text {st }}$ trimester } \\
\hline NT only & 8.1 & 20 & 55 & 54 & 68 & 12.9 & 25 & 55 & 33 & 60 \\
\hline PAPP-A + f- $\beta$ hCG & 7.1 & 16 & 42 & 46 & 67 & 5.5 & 12.1 & 33 & 52 & 74 \\
\hline Combined ${ }^{\dagger}$ & 1.2 & 3.8 & 18 & 72 & 85 & 2.3 & 6.1 & 22 & 66 & 83 \\
\hline \multicolumn{11}{|l|}{ 1st $+2^{\text {nd }}$ trimester: } \\
\hline Serum integrated $\ddagger \S$ & 1.2 & 3.6 & 15 & 70 & 86 & 0.8 & 2.7 & 12.5 & 77 & 90 \\
\hline Full integrated§ & 0.2 & 0.6 & 4.0 & 87 & 95 & 0.3 & 1.2 & 7.2 & 84 & 95 \\
\hline \multicolumn{11}{|l|}{$2^{\text {nd }}$ trimester } \\
\hline Triple (AFP+hCG+E3) & 7.0 & 14 & 32 & 45 & 69 & 2.9 & 7.1 & 22 & 51 & 74 \\
\hline Quad (Triple+inhibin A) & 3.1 & 7.3 & 22 & 60 & 81 & 2.6 & 6.1 & 18 & 63 & 83 \\
\hline
\end{tabular}

DR, detection rate; FPR, false positive rate; NT, nuchal translucency; PAPP-A, pregnancy associated plasma protein-A; f- $\beta$ hCG free beta subunit of human chorionic gonadotropin; Quad, second trimester quadruple screen; AFP, alphafetoprotein; $\mathrm{uE3}$, unconjugated estriol

tCombined: NT, PAPP-A, and $\mathrm{f}-\beta \mathrm{hCG}$ in the first trimester

‡Serum integrated: PAPP-A in the first trimester and quad screen in the second trimester

$\S$ Full integrated: NT and PAPP-A in the first trimester with quad screen in the second trimester

Data from Rosen T et al. Semin Perinatol 2005;29:367-75.

Table 3. Direct comparative data for the first and second trimester Down syndrome screens from the prospective FASTER and SURUSS trials.

\subsubsection{Alternatives to the integrated test}

\section{Sequential screening}

If the result of the first trimester screening test is positive, chromosomal analysis is performed immediately and if the result is negative, the second trimester screening test is performed and if the result is positive, chromosomal analysis is performed. A characteristic of this method is 
that the result of the first trimester screening test is provided to the pregnant woman and then the second trimester test is performed additionally. It can enhance the Down syndrome detection rate up to $98 \%$ but its false positive rate is also high as $17 \%{ }^{26}$

\section{Contingency screening}

If the first trimester screening test indicates high risk, chromosomal analysis is performed, and if the result indicates low risk no additional test is performed, but if it indicates moderate risk integrating screening is performed. ${ }^{27}$

\section{Genetic sonographic markers of aneuploidy}

Most of fetuses with chromosomal aberration have organs whose appearance is anomalous or abnormal, and such defects can be detected through prenatal sonography. A fetal structural anomaly may be caused by multiple factors, but it can be the result of chromosomal aberration. Therefore, if a fetal anomaly has been found, we should determine whether to perform cytogenetic analysis through amniocentesis after checking if other abnormalities accompany. Using genetic sonographic findings, we can detect pregnancies with high risk of aneuploidy at a sensitivity of $50-93 \% 28$, and the absence of genetic sonographic findings may be regarded as sure evidence for the low risk of haploidy. Genetic sonographic findings can be divided into major structural anomalies and minor anomalies. In particular, anomalies that are observed frequently also in normal fetuses and occasionally disappear with the advance of gestational age are called sonographic markers. It is generally accepted that a major anomaly is a sign of high risk of chromosomal aberration and thus chromosomal analysis is required, but it is still controversial whether additional tests are required when only a minor anomaly has been found. It is important to determine in consideration of the likelihood of chromosomal aberration on a case basis rather than applying a uniform rule to every case, and for this, we need to be familiar with the risk of chromosomal aberration and representative types of haploidy in connection to each genetic sonographic marker (Table 4).

\subsection{Major anomalies related to haploidy}

The characteristic and frequency of sonographic findings in fetuses with chromosomal aberration are various according to gestational age, and the detection of abnormal findings is affected by the reason of sonography, criteria for positive finding, the level of sonographic equipment, etc. Structural major anomalies are detected mostly by sonography in trisomy 13 and 18, but are missed relatively often in trisomy 21. Table 5 summarized structural major anomalies detected commonly in pregnancies with trisomy 13, 18 and 21 and Turner syndrome.

\subsection{Sonographic markers related to haploidy}

The most common sonographic markers in the second trimester include nuchal thickening, hyperechoic bowel, short limbs, pyelectasia, echogenic intracardiac focus, and choroid plexus cysts. In general, the risk of chromosomal aberration is higher when the number of markers is large. Table 6 summarized the likelihood ratio of haploidy when each sonographic marker has occurred singly. The likelihood ratio was calculated by sensitivity / false positive rate, and if two or more sonographic markers have occurred together, the combined likelihood ratio is the product of their respective likelihood ratios. 


\begin{tabular}{|c|c|c|c|}
\hline Structural defect & $\begin{array}{l}\text { Population } \\
\text { incidence }\end{array}$ & $\begin{array}{l}\text { Aneuploidy } \\
\text { risk }\end{array}$ & $\begin{array}{l}\text { Most common } \\
\text { aneploidy (Trisomy) }\end{array}$ \\
\hline Cystic hygroma & 1/120 EU-1/6,000 B & $60-75 \%$ & $45 X(80 \%), 21,18,13, X X Y$ \\
\hline Hydrops & $1 / 1,500-4,000 \mathrm{~B}$ & $30-80 \%$ & $13,21,18,45 X$ \\
\hline Hydrocephalus & 3-8/10,000 LB & $3-8 \%$ & 13,18 ,triploidy \\
\hline Hydranencephaly & $2 / 1,000$ IA & Minimal & \\
\hline Holoprosencephaly & 1/16,000 LB & $40-60 \%$ & $13,18,18 \mathrm{p}-$ \\
\hline Cardiac defect & 7-9/100 LB & $5-30 \%$ & $21,18,13,22,8,9$ \\
\hline Diaphragmatic hernia & $1 / 3,500-4,000 \mathrm{LB}$ & $20-25 \%$ & $13,18,21,45 X$ \\
\hline Omphalocele & $1 / 5,800 \mathrm{LB}$ & $30-40 \%$ & 13,18 \\
\hline Gastroschisis & $1 / 10,000-15,000$ LB & Minimal & \\
\hline Duodenal atresia & 1/10,000 LB & $20-30 \%$ & 21 \\
\hline Bladder outlet obstruction & $1-2 / 1,000 \mathrm{LB}$ & $20-25 \%$ & 13,18 \\
\hline Facial cleft & $1 / 700 \mathrm{LB}$ & $1 \%$ & 13,18 , deletions \\
\hline Limb reduction & $4-6 / 1,000 \mathrm{LB}$ & $8 \%$ & 18 \\
\hline Clubfoot & $1.2 / 1,000 \mathrm{LB}$ & $20-30 \%$ & $13,18,4 \mathrm{p}-, 18 \mathrm{q}-$ \\
\hline Single umbilical artery & $1 \%$ & Minimal & \\
\hline
\end{tabular}

B, birth; EU, early ultrasonography; LB, livebirth; IA, infant autopsy.

Data from Shipp TD, et al. Am J Obstet Gynecol 1998; 178: 600-2. and Nyberg DA and Crane JP. Chromosome abnormalities. In: Nyberg DA, et al. Diagnostic ultrasound of fetal anomalies: text and atlas. Chicago (IL): Year Book Medical; 1990. p. 676-724.

Table 4. Aneuploidy risk of major structural fetal malformation.

\begin{tabular}{|c|c|c|c|}
\hline Aneuploidy & Sonographic finding & Aneuploidy & Sonographic finding \\
\hline Trisomy 13 & $\begin{array}{l}\text { heart (VSD, dilated right } \\
\text { ventricle) } \\
\text { CNS (ventriculomegaly, } \\
\text { holoprosencephaly) } \\
\text { Face (midline defects, ocular } \\
\text { abnormalities) } \\
\text { Kidney(enlarged cystic kidneys) } \\
\text { IUGR with polyhydramnios }\end{array}$ & Trisomy 21 & $\begin{array}{l}\text { Heart (septal defects) } \\
\text { Abnormal fluid accumulation } \\
\text { (thickened nuchal fold, cystic } \\
\text { hygroma, fetal hydrops) } \\
\text { Abdominal malformations } \\
\text { IUGR with polyhydramnios }\end{array}$ \\
\hline Trisomy 18 & $\begin{array}{l}\text { Heart (VSD) } \\
\text { CNS (posterior fossa cyst, } \\
\text { abnormal head shape, } \\
\text { ventriculomegaly) } \\
\text { Facial anomalies } \\
\text { Choroid plexus cyst } \\
\text { Abnormal fluid accumulation } \\
\text { (thickened nuchal fold, cystic } \\
\text { hygroma, fetal hydrops) } \\
\text { Abdominal malformations } \\
\text { IUGR with polyhydramnios }\end{array}$ & $\begin{array}{l}\text { Turner } \\
\text { syndrome }\end{array}$ & $\begin{array}{l}\text { Heart (Coarctation of aorta) } \\
\text { Abnormal fluid accumulation } \\
\text { (increased nuchal } \\
\text { translucency/ thickened } \\
\text { nuchal fold, cystic hygroma, } \\
\text { feta hydrops) } \\
\text { Renal anomalies } \\
\text { Short femur or humerus }\end{array}$ \\
\hline
\end{tabular}

CNS, central nervous system; IUGR, intrauterine growth restriction; VSD, ventricular septal defect

Table 5. Sonographic finding with high incidence in different fetal chromosomal abnormalities 


\begin{tabular}{lll}
\hline & \multicolumn{2}{l}{ Likelihood ratio $(95 \%$ confidence interval) } \\
\cline { 2 - 3 } Sonographic marker & Nyberg et al. & Smith-Bindman et al. \\
\hline Nuchal thickening & $11.0(5.5-22.0)$ & $17(8-38)$ \\
Hyperechoic bowel & $6.7(2.7-16.8)$ & $6.1(3.0-12.6)$ \\
Short humerus & $5.1(1.6-16.5)$ & $7.5(4.7-12.0)$ \\
Short femur & $1.5(0.8-2.8)$ & $2.7(1.2-6.0)$ \\
Echogenic intracardiac focus & $1.8(1.0-3.0)$ & $2.8(1.5-5.5)$ \\
Pyelectasis & $1.5(0.6-3.6)$ & $1.9(0.7-5.1)$ \\
Normal ultrasound & 0.36 & - \\
\hline
\end{tabular}

Data from Nyberg DA, et al Ultrasound Obstet Gynecol 1998; 12: 8-14. and

Smith-Bindman R et al. JAMA. 2001; 285: 1044-55.

Table 6. Likelihood ratio of sonographic soft marker for fetal aneuploidy

\subsubsection{Choroid plexus cysts}

Choroid plexus cyst is found relatively commonly during the second trimester, showing a prevalence of $0.3-3.6 \% .29$ This type of cyst is known to be benign, disappearing spontaneously at the later stage of pregnancy without affecting the development of the fetus. As a sonographic marker of haploidy, choroid plexus cyst is found in $50 \%$ of fetuses with trisomy $18^{30}$ but most of the cases are accompanied by another anomaly, and it is reported that no particular prenatal care including chromosomal analysis is necessary if only isolated choroid plexus cysts are found. ${ }^{29}$

\subsubsection{Mild cerebral ventricular dilatation}

Mild cerebral ventricular dilatation, in which the diameter of the cerebral lateral ventricle is over 10-15 mm, is related to aneuploidy like trisomy $21 .{ }^{32}$ Bromley et al. ${ }^{32}$ reported that $12 \%$ of pregnancies with mild cerebral ventricular dilatation are related to abnormal karyotype (trisomy 18, 21). In addition, mild cerebral ventricular dilatation was observed in $4.3 \%$ of fetuses with trisomy $21^{33}$ and all of them had accompanying anomalies. It is known that the presence of cerebral ventricular dilatation alone does not increase the risk of chromosomal aberration.

\subsubsection{Nuchal thickening}

Excessive skin on the back neck is a characteristic finding of trisomy 21. It is observed in $80 \%$ of neonates with trisomy 21 and can be found in other chromosomal aberrations (trisomy 13 and 18, 45X). ${ }^{34}$ Although the sensitivity and the false positive rate vary according to gestational age and criteria for positive value are different among institutions, its sensitivity for detecting chromosomal aberrations is generally within the range of $20-40 \%$.

\subsubsection{Hyper-echoic bowel}

Hyper-echoic bowel is found in $0.5 \%$ of normal fetuses, but in fetuses with aneuploidy like trisomy 21, it is known to be observed more frequently and increase the risk 6-7 times higher. ${ }^{35}$ Assuming that the likelihood ratio of isolated hyper-echoic bowel is 6.7 and the total risk of Down syndrome in the entire population is one per 500, isolated echoic bowel is 
expected to be related to the risk of Down syndrome in around 1-2\% of the general population. Hyper-echoic bowel is also known to be related to ileus, congenital infection, and rarely to secondary meconium ileus in cystic fibrosis. ${ }^{36}$

\subsubsection{Skeletal abnormalities such as shortened limbs}

Shortened limbs are a characteristic observed in fetuses with trisomy $21^{37}$ and the length of shortened humerus seems to be a slightly more specific marker than the length of shortened femur. These results may be different according to gestational age, racial group, expected sex of the fetus, and used criteria.

\subsubsection{Echogenic intracardiac focus}

Echogenic intracardiac focus is a common finding in the second trimester. It is observed in $3-4 \%$ of normal fetuses and disappears spontaneously in the third trimester. ${ }^{39}$ If the size of echogenic intracardiac focus is large or there are multiple of them, the risk of aneuploidy increases. Bromley et al. ${ }^{40}$ reported that the risk of aneuploidy is 2 times higher when echogenic intracardiac focuses are in the right ventricle or bilateral than when they are only in the left ventricle.

\section{Conclusions}

Chromosomal aberration is closely related to the in intrauterine fetal death and perinatal prevalence. However, amniocentesis and chorionic villus sampling used for prenatal diagnosis of haploidy are invasive methods, and the reported fetal loss rate resulting just from the examinations is around 1-2\%. Accordingly, it is very important to screen those with high risk of chromosomal aberration before such invasive examinations.

Serologic test of pregnant women for the screening of trisomy 18 and 21 is an important diagnostic process in prenatal care, and in particular, second trimester serum alpha fetoprotein is used as an important screening marker to detect anomalies such as fetal neural tube defect. If the concentration of alpha fetoprotein is over $2.5 \mathrm{MoM}$, sonography should be performed in order to detect neural tube defect and other problems. Recently, because sonography shows a high detection rate for neural tube defect, amniocentesis is used less frequently in diagnosing neural tube defect.

The preferred type of serum screening test is various among countries and institutions. In general, the first trimester screening test is increasingly preferred, but second trimester screening is still used frequently at hospitals that cannot measure fetal nuchal translucency or perform chorionic villus sampling. The triple test has been used commonly as second trimester screening, but recently the use of the quad test, which adds inhibin A, is increasing. If both first and second trimester tests are performed, they can increase the detection rate of fetal anomalies, but because the two tests have to be applied at an interval of 3-4 weeks, it is quite important to provide an adequate explanation to the patient. The serum screening test can be performed in various ways depending on the combination of serum factors. Thus, rather than using a uniform test for every case, we need to understand the characteristic, detection rate and false positive rate of each test, and individualize the test for each case according to maternal age, sonographic findings, and compliance.

In conclusion, in order to determine the risk of chromosomal aberration, we should analyze each case based on maternal age, nuchal fold thickness in the first trimester, the results of 
maternal serum screening in the first or second trimester, and sonographic findings in the second trimester. Through this approach, we may reduce the number of unnecessary chromosomal analyses, lower the fetal loss rate resulting from invasive examination, and enhance the accuracy of screening for fetal chromosomal aberrations.

\section{References}

[1] Nielsen J, Wohlert M. Chromosome abnormalities found among 34,910 newborn children: results from a 13-year incidence study in Arhus, Denmark. Hum Genet 1991; 87: 81-3.

[2] Ferguson-Smith MA, Yates JR. Maternal age specific rates for chromosome aberrations and factors influencing them: report of a collaborative european study on 52,965 amniocenteses. Prenat Diagn 1984; 4: 5-44.

[3] Munné S, Sultan KM, Weier HU, Grifo JA, Cohen J, Rosenwaks Z. Assessment of numeric abnormalities of $X, Y, 18$, and 16 chromosomes in preimplantation human embryos before transfer. Am J Obstet Gynecol 1995; 172(4 Pt 1): 1191-9.

[4] Snijders RJ, Sundberg K, Holzgreve W, Henry G, Nicolaides KH. Maternal age- and gestation-specific risk for trisomy 21. Ultrasound Obstet Gynecol 1999; 13: 167-70.

[5] Li MM, Howard-Peebles PN, Killos LD, Fallon L, Listgarten E, Stanley WS. Characterization and clinical implications of marker chromosomes identified at prenatal diagnosis. Prenat Diagn 2000; 20 : 138-43.

[6] Warburton D. De novo balanced chromosome rearrangements and extra marker chromosomes identified at prenatal diagnosis: clinical significance and distribution of breakpoints. Am J Hum Genet 1991; 49: 995-1013.

[7] American College of Obstetricians and Gynecologists. ACOG Practice Bulletin No. 88, December 2007. Invasive prenatal testing for aneuploidy. Obstet Gynecol 2007; 110: 1459-67.

[8] Haddow JE. Prenatal screening for open neural tube defects, Down's syndrome, and other major fetal disorders. Semin Perinatol 1990; 14: 488-503.

[9] Haddow JE, Kloza EM, Knight GJ, Smith DE. Relation between maternal weight and serum alpha-fetoprotein concentration during the second trimester. Clin Chem 1981; 27: 133-4.

[10] Wald NJ, Cuckle H, Boreham J, Stirrat GM, Turnbull AC. Maternal serum alphafetoprotein and diabetes mellitus. Br J Obstet Gynaecol 1979; 86: 101-5.

[11] Palomaki GE, Hill LE, Knight GJ, Haddow JE, Carpenter M. Second-trimester maternal serum alpha-fetoprotein levels in pregnancies associated with gastroschisis and omphalocele. Obstet Gynecol 1988; 71(6 Pt 1): 906-9.

[12] Albright SG, Warner AA, Seeds JW, Burton BK. Congenital nephrosis as a cause of elevated alpha-fetoprotein. Obstet Gynecol 1990; 76(5 Pt 2): 969-71.

[13] Wald NJ, Hackshaw AK, George LM. Assay precision of serum alpha fetoprotein in antenatal screening for neural tube defects and Down's syndrome. J Med Screen 2000; 7: 74-7.

[14] Bernstein IM, Barth RA, Miller R, Capeless EL. Elevated maternal serum alphafetoprotein: association with placental sonolucencies, fetomaternal hemorrhage, vaginal bleeding, and pregnancy outcome in the absence of fetal anomalies. Obstet Gynecol 1992; 79: 71-4. 
[15] Butler EL, Dashe JS, Ramus RM. Association between maternal serum alphafetoprotein and adverse outcomes in pregnancies with placenta previa. Obstet Gynecol 2001; 97: 35-8.

[16] Merkatz IR, Nitowsky HM, Macri JN, Johnson WE. An association between low maternal serum alpha-fetoprotein and fetal chromosomal abnormalities. Am J Obstet Gynecol 1984; 148: 886-94.

[17] Wald NJ, Cuckle HS, Densem JW, Nanchahal K, Royston P, Chard T, et al. Maternal serum screening for Down's syndrome in early pregnancy. BMJ 1988; 297: 883-7.

[18] Wald NJ, Densem JW, George L, Muttukrishna S, Knight PG. Prenatal screening for Down's syndrome using inhibin-A as a serum marker. Prenat Diagn 1996; 16: 14353.

[19] Wald NJ, Rodeck C, Hackshaw AK, Walters J, Chitty L, Mackinson AM. First and second trimester antenatal screening for Down's syndrome: the results of the Serum, Urine and Ultrasound Screening Study (SURUSS). J Med Screen 2003; 10: 56-104.

[20] Malone FD, Canick JA, Ball RH, Nyberg DA, Comstock CH, Bukowski R, et al. Firstand Second-Trimester Evaluation of Risk (FASTER) Research Consortium. Firsttrimester or second-trimester screening, or both, for Down's syndrome. N Engl J Med 2005; 353: 2001-11.

[21] Benn PA, Leo MV, Rodis JF, Beazoglou T, Collins R, Horne D. Maternal serum screening for feta trisomy 18: a comparion of fixed cut off and patient-specific risk protocols. Obstet Gyenecol 1999; 93: 707-11.

[22] Brizot ML, Snijders RJ, Butler J, Bersinger NA, Nicolaides KH. Maternal serum hCG and fetal nuchal translucency thickness for the prediction of fetal trisomies in the first trimester of pregnancy.Br J Obstet Gynaecol 1995; 102: 127-32.

[23] Rosen T, D'Alton ME. Down syndrome screening in the first and second trimesters: what do the data show? Semin Perinatol 2005; 29: 367-75.

[24] Berry E, Aitken DA, Crossley JA, Macri JN, Connor JM. Screening for Down's syndrome: changes in marker levels and detection rates between first and second trimesters. Br J Obstet Gynaecol 1997; 104: 811-7.

[25] Spencer K, Souter V, Tul N, Snijders R, Nicolaides KH. A screening program for trisomy 21 at 10-14 weeks using fetal nuchal translucency, maternal serum free beta-human chorionic gonadotropin and pregnancy-associated plasma protein-A. Ultrasound Obstet Gynecol 1999; 13: 231-7.

[26] Wapner R, Thom E, Simpson JL, Pergament E, Silver R, Filkins K, et al. First Trimester Maternal Serum Biochemistry and Fetal Nuchal Translucency Screening (BUN) Study Group.First-trimester screening for trisomies 21 and 18. N Engl J Med 2003; 349: 1405-13.

[27] Cuckle H, Benn P, Wright D. Down syndrome screening in the first and/or second trimester: model predicted performance using meta-analysis parameters. Semin Perinatol 2005; 29: 252-7.

[28] Shipp TD, Benacerraf BR. Second trimester ultrasound screening for chromosomal abnormalities. Prenat Diagn 2002; 22: 296-307.

[29] Yoder PR, Sabbagha RE, Gross SJ, Zelop CM. The second-trimester fetus with isolated choroid plexus cysts: a meta-analysis of risk of trisomies 18 and 21.Obstet Gynecol 1999; 93(5 Pt 2): 869-72. 
[30] Snijders RJ, Shawa L, Nicolaides KH. Fetal choroid plexus cysts and trisomy 18: assessment of risk based on ultrasound findings and maternal age. Prenat Diagn 1994; 14: 1119-27.

[31] Vintzileos AM, Ananth CV, Fisher AJ, Smulian JC, Day-Salvatore D, Beazoglou T, et al. An economic evaluation of prenatal strategies for detection of trisomy 18. Am J Obstet Gynecol 1998; 179: 1220-4.

[32] Bromley B, Frigoletto FD Jr, Benacerraf BR. Mild fetal lateral cerebral ventriculomegaly: clinical course and outcome. Am J Obstet Gynecol 1991; 164: 8637.

[33] Nyberg DA, Souter VL, El-Bastawissi A, Young S, Luthhardt F, Luthy DA. Isolated sonographic markers for detection of fetal Down syndrome in the second trimester of pregnancy. J Ultrasound Med 2001; 20: 1053-63.

[34] Borrell A, Costa D, Martinez JM, Delgado RD, Casals E, Ojuel J, et al. Early midtrimester fetal nuchal thickness: effectiveness as a marker of Down syndrome. Am J Obstet Gynecol 1996; 175: 45-9.

[35] Nyberg DA, Resta RG, Luthy DA, Hickok DE, Mahony BS, Hirsch JH. Prenatal sonographic findings of Down syndrome: review of 94 cases. Obstet Gynecol 1990; 76(3 Pt 1): 370-7.

[36] Muller F, Dommergues M, Aubry MC, Simon-Bouy B, Gautier E, Oury JF, et al. Hyperechogenic fetal bowel: an ultrasonographic marker for adverse fetal and neonatal outcome. Am J Obstet Gynecol 1995; 173: 508-13.

[37] Benacerraf BR, Neuberg D, Frigoletto FD Jr. Humeral shortening in second-trimester fetuses with Down syndrome.Obstet Gynecol 1991; 77: 223-7.

[38] Petrikovsky BM, Challenger M, Wyse LJ. Natural history of echogenic foci within ventricles of the fetal heart. Ultrasound Obstet Gynecol 1995; 5: 92-4.

[39] Bromley B, Lieberman E, Shipp TD, Richardson M, Benacerraf BR. Significance of an echogenic intracardiac focus in fetuses at high and low risk for aneuploidy. J Ultrasound Med 1998; 17: 127-31. 


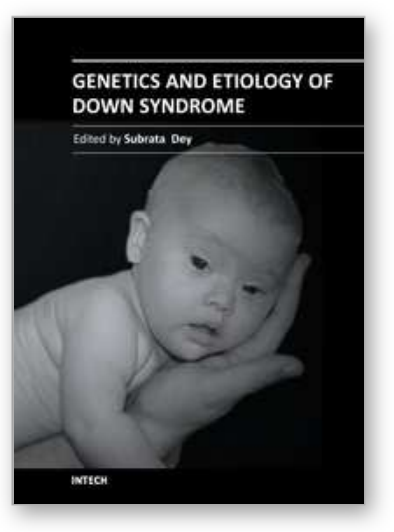

\author{
Genetics and Etiology of Down Syndrome \\ Edited by Prof. Subrata Dey
}

ISBN 978-953-307-631-7

Hard cover, 328 pages

Publisher InTech

Published online 29, August, 2011

Published in print edition August, 2011

This book provides a concise yet comprehensive source of current information on Down syndrome. Research workers, scientists, medical graduates and paediatricians will find it an excellent source for reference and review. This book has been divided into four sections, beginning with the Genetics and Etiology and ending with Prenatal Diagnosis and Screening. Inside, you will find state-of-the-art information on: 1. Genetics and Etiology 2. Down syndrome Model 3. Neurologic, Urologic, Dental \& Allergic disorders 4. Prenatal Diagnosis and Screening Whilst aimed primarily at research workers on Down syndrome, we hope that the appeal of this book will extend beyond the narrow confines of academic interest and be of interest to a wider audience, especially parents and relatives of Down syndrome patients.

\title{
How to reference
}

In order to correctly reference this scholarly work, feel free to copy and paste the following:

Myungshin Kim, Jong Chul Shin and In Yang Park (2011). Prenatal Diagnosis of Down Syndrome, Genetics and Etiology of Down Syndrome, Prof. Subrata Dey (Ed.), ISBN: 978-953-307-631-7, InTech, Available from: http://www.intechopen.com/books/genetics-and-etiology-of-down-syndrome/prenatal-diagnosis-of-downsyndrome

\section{INTECH}

open science | open minds

\section{InTech Europe}

University Campus STeP Ri

Slavka Krautzeka 83/A

51000 Rijeka, Croatia

Phone: +385 (51) 770447

Fax: +385 (51) 686166

www.intechopen.com

\section{InTech China}

Unit 405, Office Block, Hotel Equatorial Shanghai

No.65, Yan An Road (West), Shanghai, 200040, China 中国上海市延安西路65号上海国际贵都大饭店办公楼405单元

Phone: +86-21-62489820

Fax: $+86-21-62489821$ 
(C) 2011 The Author(s). Licensee IntechOpen. This chapter is distributed under the terms of the Creative Commons Attribution-NonCommercialShareAlike-3.0 License, which permits use, distribution and reproduction for non-commercial purposes, provided the original is properly cited and derivative works building on this content are distributed under the same license. 